\title{
UN CASO SINGULAR DE ESTATUA ROMANA DE CULTO DOMÉSTICO
}

\author{
POR \\ MARÍA PÉREZ RUIZ ${ }^{1}$ \\ Universidad Autónoma de Madrid
}

\begin{abstract}
RESUMEN
El Museo Arqueológico Provincial de Badajoz cuenta entre su colección con una singular escultura romana que, por su iconografía, puede ser identificada como la representación de un dios Lar pero cuyo material y dimensiones hacen de ella una pieza sin paralelos conocidos hasta la fecha. La singularidad de ambas características la convierte en objeto de un particular interés en el estudio y la comprensión del culto doméstico romano en general y, concretamente, en Hispania.
\end{abstract}

\section{SUMMARY}

The Provincial Archaeological Museum of Badajoz includes in its Roman art collection a singular sculpture which, due to its iconography, can most probably be identified as the representation of a Lar. However, the fact that it was sculptured in marble and its large dimensions make it a piece unparalleled till now. These two singular features highlight the particular interest of this sculpture for the study and understanding of the Roman domestic cult, particularly in Hispania.

PALABRAS CLAVE: Escultura romana. Culto doméstico. Hispania. Lar.

KEY WORDS: Roman sculpture. Domestic cult. Hispania. Lar.

\section{PRESENTACIÓN DE LA PIEZA Y ESTUDIOS PREVIOS}

El Lar del Museo Arqueológico Provincia de Badajoz (MAPB. Fig. 1) $)^{2}$ fue hallado «por un obrero del campo, en las inmediaciones de Mérida, al practicar trabajos agrícolas» según Romero de Cas-

\footnotetext{
${ }^{1}$ Este trabajo ha sido realizado gracias a una beca FPU del MEC (AP-2004-4978), adscrita al Dpto. Prehistoria y Arqueología de la Universidad Autónoma de Madrid. E-mail: maria.perez@uam.es.

Agradecemos a D. Guillermo Kurtz y a Dña. Coronada Domínguez de la Concha, director —en el momento en el que visitamos el museo- y conservadora respectivamente del Museo Arqueológico Provincial de Badajoz, las facilidades mostradas para acceder a la pieza, así como su amabilidad y sus oportunas apreciaciones. Agradecemos, así mismo, al Prof. Bendala su sugerencia de abordar este trabajo, así como su ayuda, sus consejos y su interés.

${ }^{2} \mathrm{~N}^{\mathrm{o}}$ inv. 231. Expuesta en la sala dedicada a la época romana.
}

tilla (Romero de Castilla, T., 1896, 51), quien describe que debió aparecer poco antes de su compra para el museo el 4 de julio de 1871, hallándose junto a ella únicamente una hoz (falx stramentaria. Fig. 2) y una podadera (arboraria sylvatica. Fig. 3. Ibid., 51 y 119-120). Aparte de la descripción de la pieza, sus medidas y estado de conservación, nada más aportó sobre su hallazgo y su contexto.

El siguiente estudio, realizado por Mélida (Mélida, J. R., 1925, n. o 1469, lám. CVIII, fig. 148), siguió de cerca esta descripción, pero aportando la identificación de la pieza con un Lar, frente a las posibles adscripciones iconográficas dadas por Romero de Castilla. Identificación seguida en todas sus demás publicaciones ${ }^{3}$, incluido el único estudio monográfico (Álvarez Martínez, J. M., 1975) y en el que destacan las hipótesis de la procedencia de la pieza de una villa cercana a Mérida y de la identificación del material con mármol de Borba-Estremoz (Portugal), así como la propuesta de una cronología (mediados del s. I d.C.) a partir del estudio del peinado. Los estudios posteriores han seguido a grandes rasgos este trabajo, si bien cabe destacar la mención al taller local que, dadas las características de la técnica y el material, podría haberla ejecutado (Nogales, T., 1997, 407).

\section{ANÁLISIS TÉCNICO, ESTILÍSTICO E ICONOGRÁFICO}

Escultura en bulto redondo de $0,97 \mathrm{~m}$ de altura ${ }^{4}$, realizada en mármol local ${ }^{5}$ de grano grueso y color

\footnotetext{
${ }^{3}$ García y Bellido, A., 1949, no 100, lám. 81; Álvarez Martínez, J. M ${ }^{\mathrm{a}}$, 1975; Portela, $\mathrm{M}^{\mathrm{a}}$ I., 1984, 170-171, fig. 6; Álvarez Martínez, J. Ma y Nogales, T., 1992-1993, 287-289, fig. 8; Rodríguez Oliva, P., 1994, 25; Nogales, T., 1997, 407; Creus, M ${ }^{a}$ L., 2002, 256-257, fig. 2; Marco, H., 1999.

${ }^{4}$ Altura total de la pieza con el plinto. Altura del plinto $7 \mathrm{~cm}$.

${ }^{5} \mathrm{Si}$ bien en varias publicaciones de la pieza se afirma que se trata de mármol procedente de las canteras de Borba-Estremoz, a falta de un estudio petrológico preferimos hablar simplemente de mármol local, ya que su calidad no justificaría que hubiera sido importado.
} 


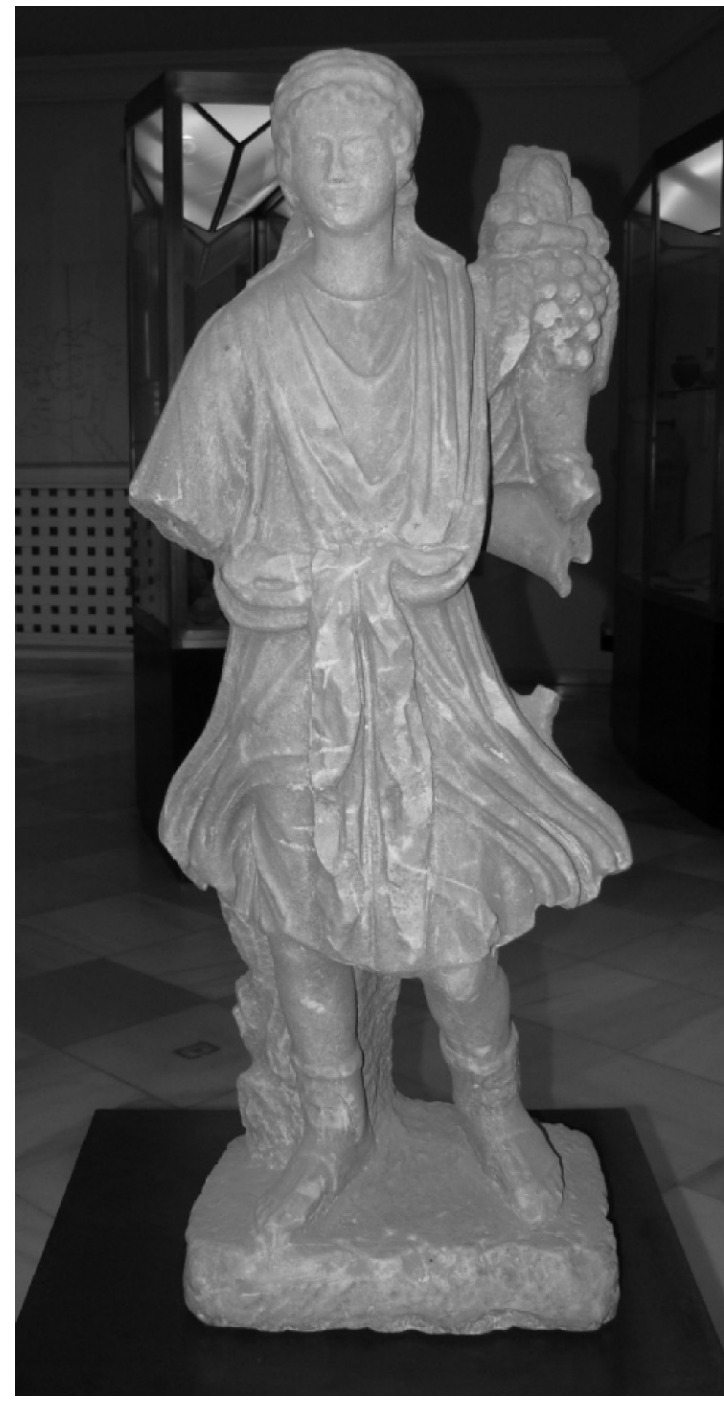

Fig. 1. Lar del MAPB. Vista frontal ( M. Pérez Ruiz).

blanco marfileño, apreciable en las zonas donde hay rotura. La superficie de la pieza se encuentra bastante deteriorada, como evidencia el alto grado de erosión sufrido en el rostro y el calzado. Una pátina de tierra rojiza cubre toda la escultura salvo en aquellas zonas donde se han producido leves pérdidas recientes (cornucopia, túnica y pies). Se han perdido así mismo el antebrazo derecho, parte del antebrazo izquierdo (realizados ambos en pieza aparte) y la parte inferior y el remate superior de la cornucopia. El orificio para el encaje del brazo izquierdo muestra una rotura que parece antigua, aparentemente fruto de una restauración mal ejecutada.

La escultura representa a un joven estante en posición prácticamente frontal, rota por el leve giro hacia la derecha de cabeza, cadera y pierna derecha; la pierna izquierda está ligeramente flexionada con el pie orientado hacia la izquierda. Las proporciones dadas a la pieza hacen que ésta tenga un aspecto estilizado. Se apoya en un bloque apenas desbastado junto a la pierna derecha y que sugiere un tronco escasamente esbozado. La parte posterior y otras poco visibles, han sido trabajadas de forma muy somera (Fig. 4).

El rostro (Fig. 5) tiene forma ovalada de tendencia triangular y gesto serio imprimido por la unión de ambos labios. La escasa calidad del material no habría permitido su trabajo en detalle, si bien destaca un leve resto del surco que dibujaría el iris del ojo derecho, así como del vaciado de la pupila ${ }^{6}$ (Fig. 6). El pelo rizado aparece más marcado en los bucles de la frente y que caen sobre las orejas (Fig. 7), mientras que en la zona superior de la cabeza se convierte en simples surcos ondulados recogidos en una coleta en la parte trasera (Fig. 4). Se toca con una corona vegetal, probablemente de espigas, dispuesta en tres hileras de la que penden dos infulae que caen sobre los hombros; en su contorno inferior se debió aplicar algún tipo de fruto en otro material, como demuestra la presencia de pequeños orificios (Figs. 5 у 7$)$.

La figura viste una túnica corta sobre la que porta un pallium sostenido en el hombro izquierdo que se cruza en la espalda y se recoge a modo de cinturón, con sus dos extremos pendiendo de él. Los pliegues están marcados mediante agudos ángulos alrededor del cuello y un trépano profundo, especialmente visible en las ondas de la túnica, con las que se trata a su vez de transmitir una sensación de movimiento. Se calza con bota alta tipo embas, ceñida a la pierna por una cinta con dibujo de ochos, en la variante que deja los dedos al descubierto y rematada en su parte superior por una piel de cánido, de la que penden la cabeza y las patas sobre la parte delantera.

De los atributos se conserva aún buena parte de la cornucopia, sujeta por el brazo izquierdo y de la cual rebosan, entre otros frutos, espigas, uvas o la piña que la corona. Con la mano derecha debió sujetar una patera, en función de la posición en ángulo recto que parece inferirse de la trayectoria del orificio de encastre del antebrazo perdido.

En función de lo descrito, la escultura se ajusta al modelo iconográfico de los dioses Lares. Queda, por tanto, descartada su identificación con Vertum-

\footnotetext{
${ }^{6}$ Este detalle no fue recogido por Álvarez Martínez, quien afirma en su descripción: «Ojos con pupilas sin marcar» $(1975,870)$.
} 


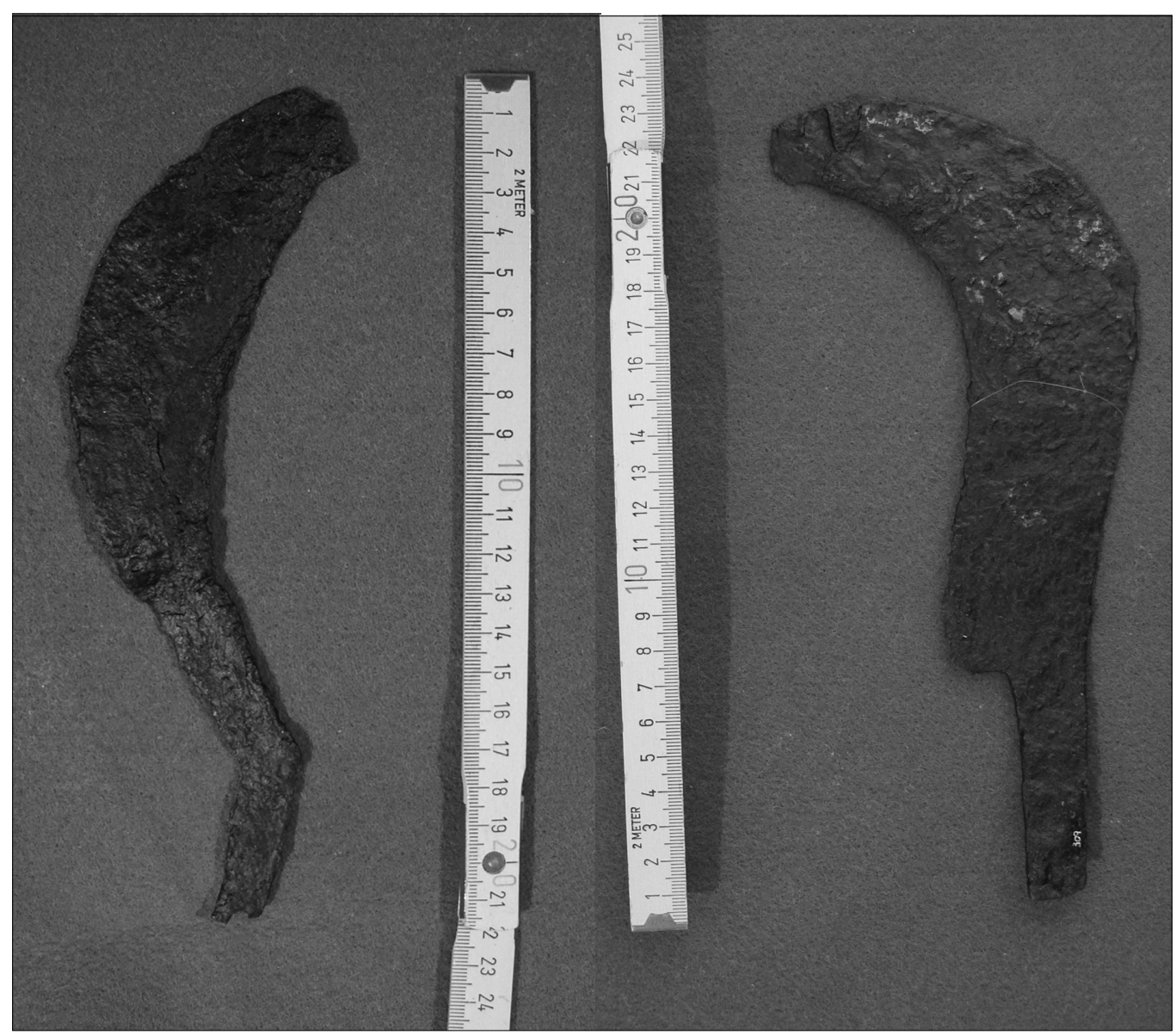

Fig. 2 y 3. 2, Hoz aparecida a los pies del Lar (@ M. Pérez Ruiz). 3, Podadera aparecida a los pies del Lar (C M. Pérez Ruiz).

nus o Pomona ${ }^{7}$ (Romero de Castilla, T., 1896, 50). De los dos tipos en los que se agrupan las representaciones de Lares - compitales (tipo I) y familiares (tipo II $)^{8}$ - y atendiendo a las características que los diferencian (atributos, detalles del vestido y postura), la escultura del MAPB encaja en el tipo II.

Sin embargo, esta pieza presenta dos peculiaridades que no son comunes en las representaciones de Lares. La primera es su factura en piedra. Existen diversos ejemplos pétreos de Lares en los relieves de los altares dedicados al culto imperial; sin embargo, no

${ }^{7}$ El carácter metamórfico del dios Vertumnus, presentado así en las fuentes (ver Segarra, D., 2003, 129-130 con bibliografía), implica el desconocimiento del aspecto exacto de sus representaciones (Penny Small, J., 1997, 235), de manera que sólo se tienen algunas identificaciones dudosas, que no guardan, por otro lado, relación con nuestra pieza (ibid.; Esperandieu, E., 1908, 135-136, n ${ }^{\circ} 1076$ ). La identificación con Pomona queda descartada por el hecho de que nuestra estatua es masculina. ocurre lo mismo con la escultura de bulto redondo, realizada toda ella en bronce (Tran Tam Tinh, V., 1992, 211), lo cual pone de manifiesto lo excepcional de esta pieza. Hemos hallado únicamente como esculturas en bulto redondo identificadas con posibles Lares dos hermae de mármol (Jordan, H., 1882, 70-71 y lám. M; Visconti, C. L., 1884-1885, 280 y lám. CIII. Fig. 8) del Museo Torlonia (Roma, Italia), los cuales son en sí mismos únicos ${ }^{9} \mathrm{y}$ comparten escaso parecido con nuestro Lar. Con importantes similitudes estilísticas e iconográficas destacamos una cabeza de sátiro (Fig. 9) del Museo Archeologico di Aquileia (Udine, Italia). Ésta presenta un peinado de rizos que le enmarca la

\footnotetext{
${ }^{8}$ Seguimos la división presentada en el LIMC por Tran Tam Tinh en la voz dedicada al Lar (Tran Tam Tinh, V., 1992).

${ }^{9}$ Su identificación con dioses Lares se debe a la presencia de la bulla pendiendo de su cuello (Jordan, H., 1882, 71). Aunque no es frecuente esta representación, sí aparecen mencionados en las fuentes como Lares bullati (Petronio 60).
} 


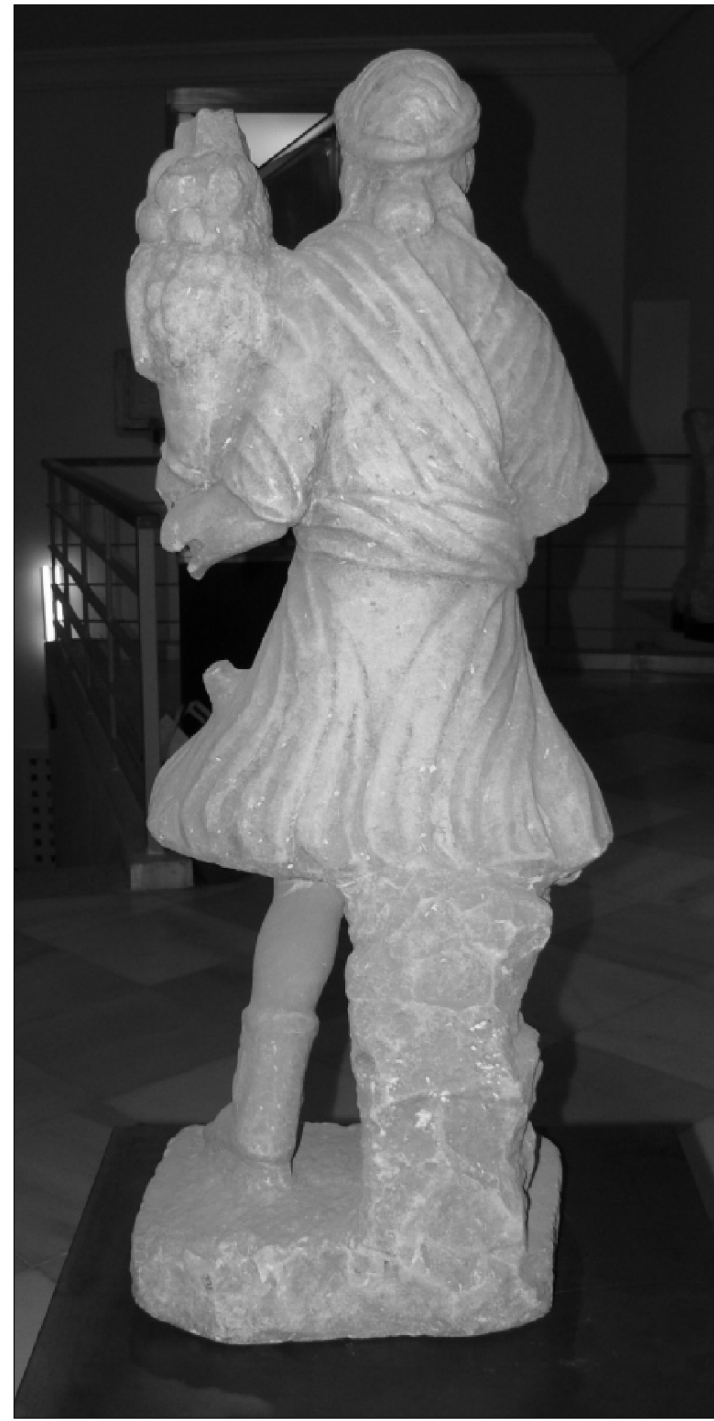

Fig. 4. Lar del MAPB. Vista trasera (@ M. Pérez Ruiz).

frente y está tocada con una corona formada por tres hileras paralelas de lo que parecen espigas. La diferencia más notable son sus orejas puntiagudas, que han llevado a identificarlo con un sátiro (Scrinari, V. S. M., 1972, 46 y fig. 126, n. ${ }^{\circ}$ 127) o Fauno (Vergnani, M., 1964, 203 y lám. LXV, 127, no 298). La segunda peculiaridad es el tamaño de la pieza, de casi un metro de altura, frente a los $12 \mathrm{~cm}$ de media que, salvo excepciones, suelen alcanzar las estatuillas de bronce (Boucher, S. y Oggiano-Bitar, H., 1995, 233).

A pesar de ambas peculiaridades, la comparación de esta figura con las estatuillas de bronce encontradas por todo el Imperio en contextos domésticos, así como con las pinturas conservadas de lararios, resuel- ve las dudas respecto a su adscripción iconográfica. Como ejemplos más cercanos de bulto redondo en bronce podemos citar, entre otros, una estatuilla de Lar $^{10}$ procedente de las cercanías de Albano (Walters, H. B., 1899, 254, no 1562), el Lar ${ }^{11}$ de bronce del Cleveland Museum of Art (Kozloff, A. P. y Mitten, D. G., 1988, 326-327), los Lares ${ }^{12}$ hallados en la casa V.4.3 de Pompeya (Sogliano, A., 1899, 206 y fig. 1) o las figurillas ${ }^{13}$ encontradas en Cachette de Bavay (Francia. Boucher, S. y Oggiano-Bitar, H., 1993, pp. 87-88 y figs. 18-19). El paralelo peninsular más cercano es el Lar ${ }^{14}$ de Pollentia (La Alcudia, Mallorca. Portela, $M^{\mathrm{a}}$ I., 1984, 171 y fig. 8$)^{15}$. Un rasgo atípico en el Lar del MAPB es el recogido trasero del pelo en una coleta, cuyo mejor paralelo es la estatuilla procedente de Torre Annunziata (Italia ${ }^{16}$. Walters, H. B. 1899, 255; Fototeca IGR).

\section{PROPUESTA DE DATACIÓN DE LA PIEZA}

La falta de un contexto al que asociar esta pieza nos obliga a proponer su cronología a partir de la información extraída de su modelo iconográfico, así como de sus características técnicas y estilísticas, mediante la búsqueda de paralelos datados. Los modelos en bronce no despejan muchas dudas por la continuidad de uso que caracteriza a las imágenes de culto: aunque el Lar tipo II es la representación más antigua ${ }^{17}$ y cayó en desuso a favor del tipo I a partir de la reforma del culto llevada a cabo por Augusto, se conocen ejemplos de estas estatuillas en contextos que llegan hasta el s. III d.C. (Boucher, S., y Oggiano-Bitar, H., 1995, 233). De manera que hay que recurrir a la peculiaridad de su factura en piedra para buscar en la escultura de este tipo los paralelos que permitan avanzar una datación. La primera propuesta (Álvarez Martínez, J. M. ${ }^{\text {, }, ~ 1975, ~ 872) ~ e s t a b l e-~}$ cía una cronología en torno a mediados del siglo I d.C. (seguida en sucesivas publicaciones) en función

\footnotetext{
${ }^{10}$ Alt.. $19,3 \mathrm{~cm}$

${ }^{11}$ Alt.: 16,2 cm. Primer cuarto del s. I d.C. aprox.

12 Alt.: $12,5 \mathrm{~cm}$.

13 Alt.: 20,2 y $31,8 \mathrm{~cm}$. Datación propuesta de época claudia.

${ }^{14}$ Alt.: $12,8 \mathrm{~cm}$.

${ }^{15}$ Los paralelos dados por J. M ${ }^{\mathrm{a}}$ Álvarez (1975, 871-872) son igualmente cercanos a esta pieza, pero hemos querido añadir aquí otros nuevos que completen la visión del Lar del MAPB en el conjunto de este tipo de representaciones.

${ }^{16}$ Alt.: $20 \mathrm{~cm}$

${ }^{17}$ No se conocen estatuillas en bronce de estas divinidades anteriores a la época imperial, pero las fuentes nos hablan de su realización en materiales perecederos, tales como la cera o la madera (Tibulo I, 10, 15-20).
} 

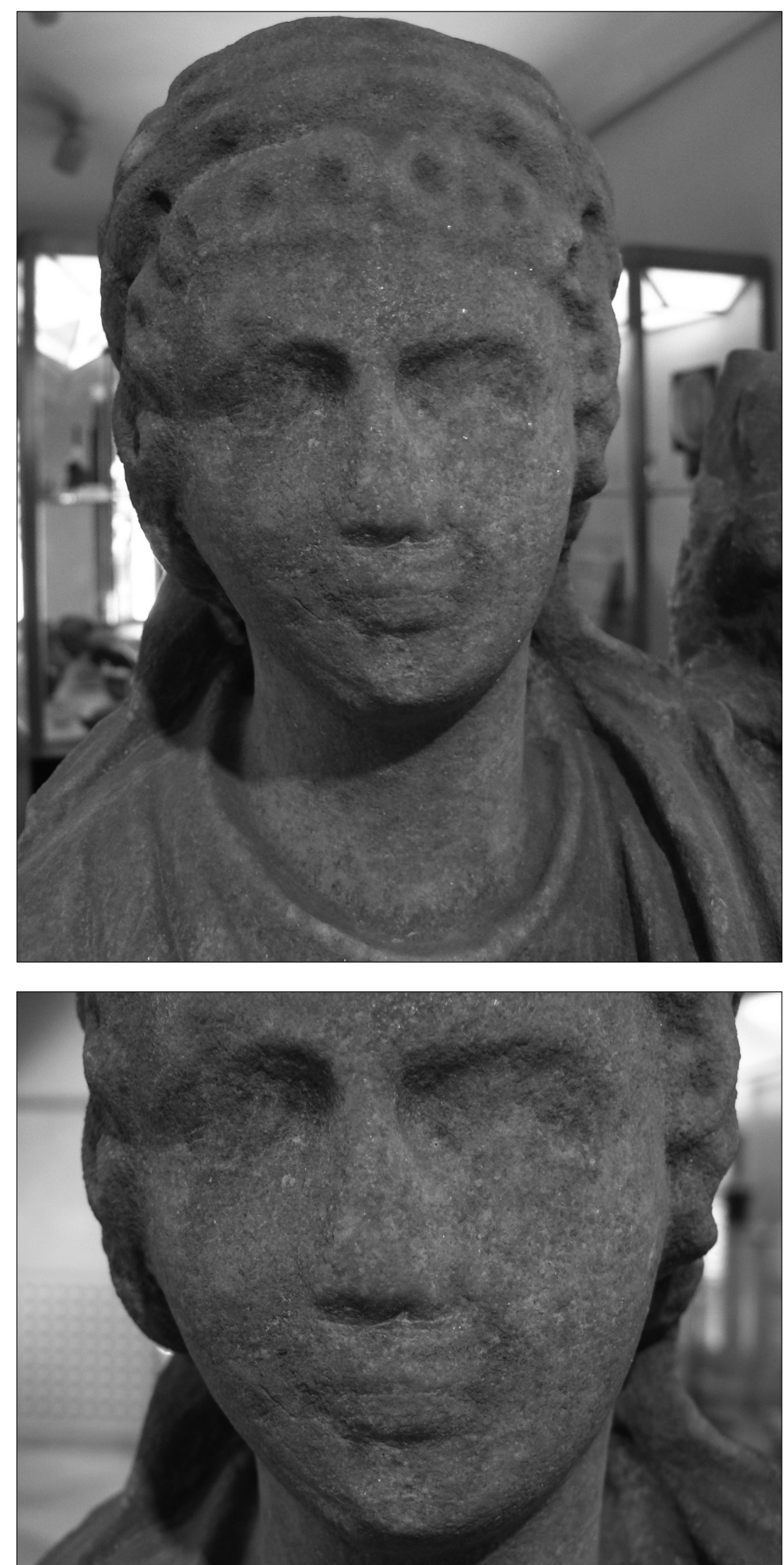

Figs. 5 y 6. 5 . Vista frontal de la cabeza (@ M. Pérez Ruiz).-6. Detalle del rostro (C) M. Pérez Ruiz). 


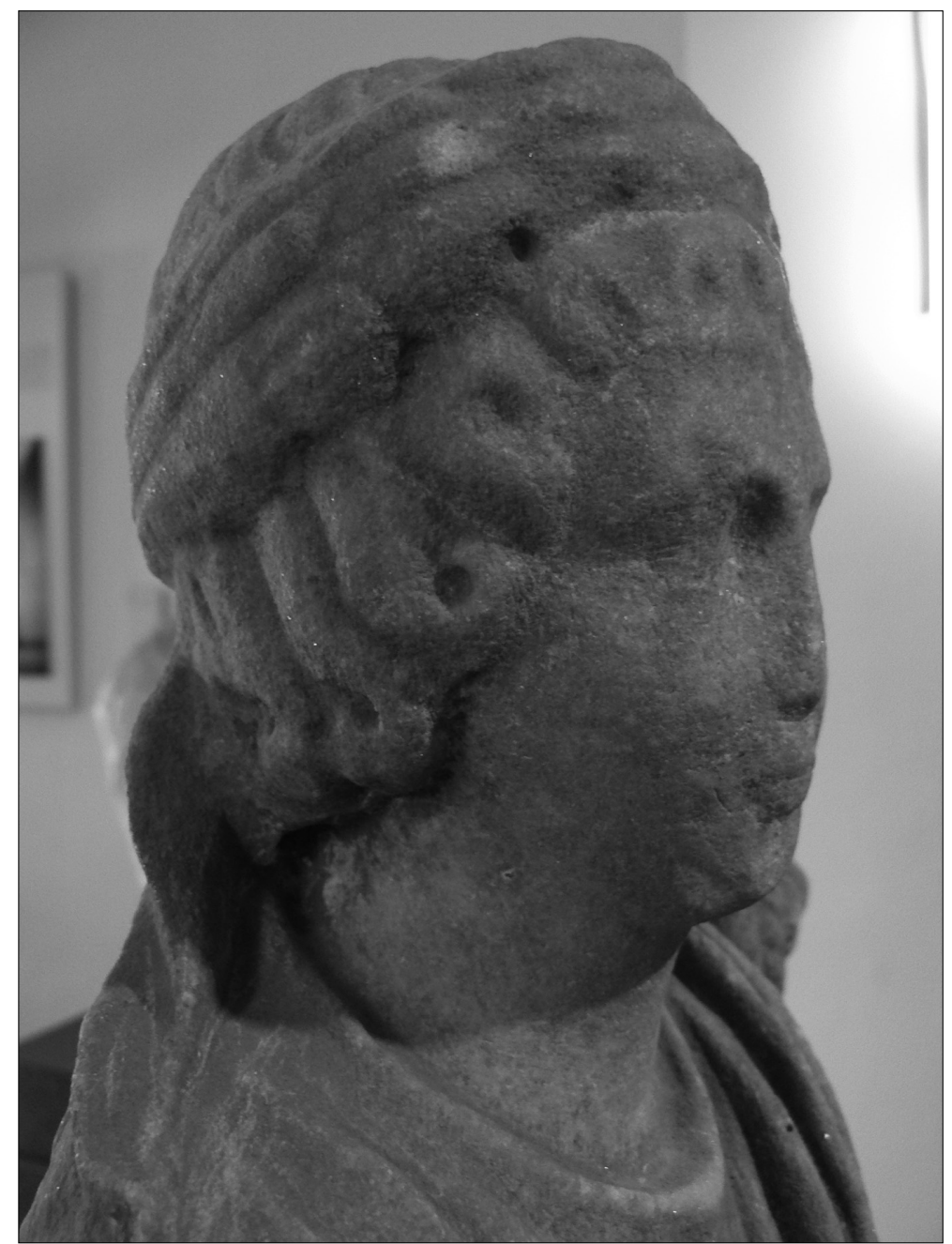

Fig. 7. Vista lateral de la cabeza (@ M. Pérez Ruiz).

de su peinado, parangonable al de algunas esculturas de este período, como los retratos de Agripina y un retrato infantil procedente de Ostia fechado entre los emperadores Claudio y Nerón. Sin embargo, este tipo de peinado se encuentra también en esculturas más tardías. En este sentido, es especialmente interesante el retrato de sacerdote de la Ny Carlsberg Glyptotek de Copenhague ( $\mathrm{n}^{\mathrm{o}}$ inv. 2757. Fig. 10), fechado en el s. IV d.C. (Poulsen, M., 1974, 203-204 y lám. CCCXLIII, no 210) y peinado y tocado de forma similar al Lar.

Desde el punto de vista iconográfico, el único paralelo válido para avanzar una cronología es la cabeza de sátiro del Museo Archeologico di Aquileia. Rasgos comunes con la cabeza del Lar son la forma triangular del rostro, los bucles que lo enmarcan o la corona triple con la que se toca. Los iris de la cabeza de Aquileia están subrayados mediante surcos profundos y sus pupilas contundentemente vaciadas, trabajo que puede apreciarse muy levemente en el ojo derecho del Lar. También los arcos supraciliales, prominentes y con tendencia depresiva en los extremos exteriores, son comunes a ambas esculturas. Son especialmente estos dos últimos rasgos los que llevan a fechar la cabeza de Aquileia en el s. III d.C.

Las características técnicas y estilísticas del Lar deben remitirse a una cronología similar. Por un lado, ésta está marcada por una estilización de sus proporciones (cuello largo que contrasta con la caída de sus hombros, cintura y caderas bajas, una cierta desproporción en la longitud del tronco frente a las piernas), que puede observarse en la escultura severiana y 


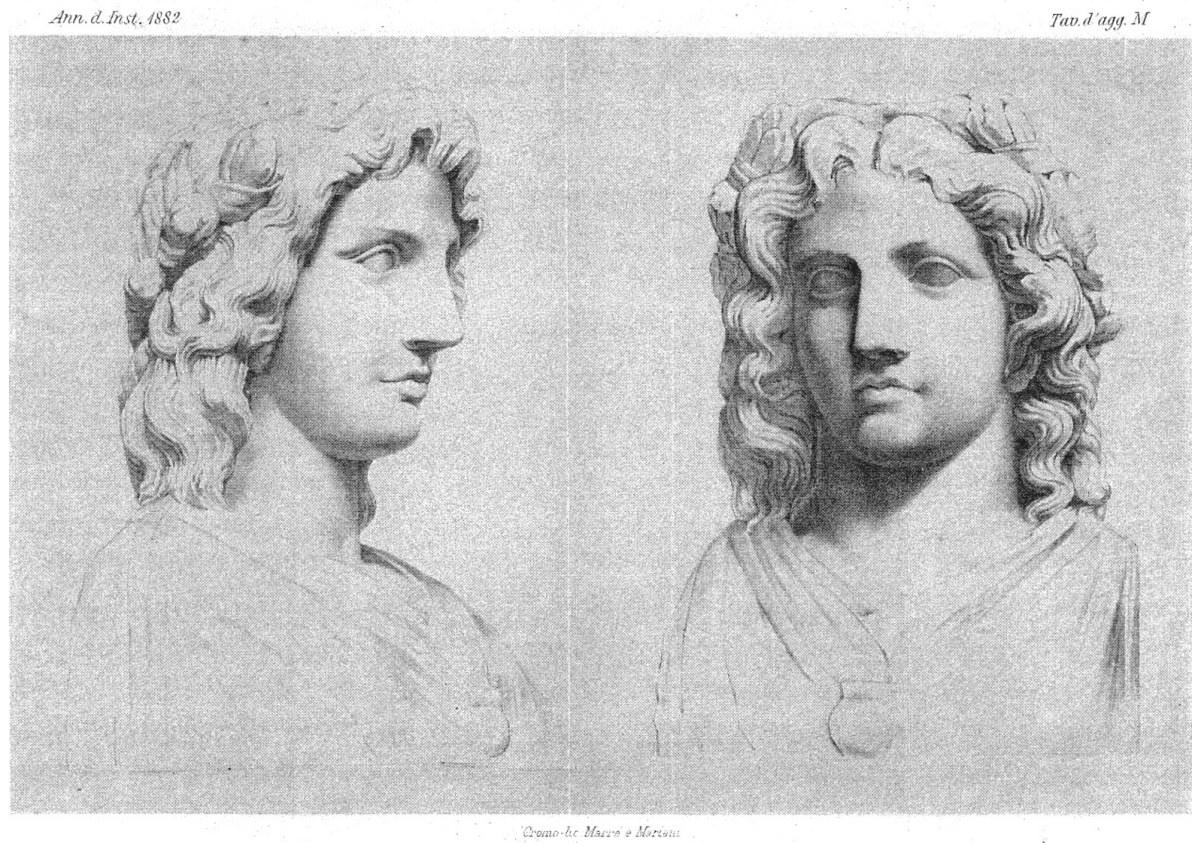

Fig. 8. Lares Torlonia (Jordan, 1882, lám. M).

postseveriana, como los relieves del arco de Septimio Severo y del arco degli Argentarii, en Roma. Comparable también por la estilización de sus proporciones es la escultura de togado (Trillmich, W., 1997, 396, $\mathrm{n}^{\text {o } 190)}$ hallada en Sevilla y fechada en el siglo III d.C. Ambas piezas presentan lo que Trillmich ha denominado estilo «pastoso» del ropaje, refiriéndose a la flaccidez de sus formas que provoca una cierta sensación de pesadez, lo cual es especialmente evidente en la curva que crea la caída de la toga, igual a la del pallium del Lar.

La figura del Lar acusa además una falta de organicidad, característica de la escultura romana a partir del siglo III (Strong, E., 1926, 407). Esto provoca la sensación de que cada una de sus partes hubiera sido trabajada de forma independiente, rompiendo la armonía del conjunto e imposibilitando la transmisión de movimiento, del cual carece la pieza a pesar de la voluntad de expresarlo en detalles como la falda de la túnica o la posición la pierna izquierda. Otro elemento que contribuye al estatismo es el tratamiento de los paños, con grandes pliegues esquemáticos y un profundo trépano muy plástico y poco naturalista que no llega nunca al borde de la túnica. Junto al estatismo, destaca la frontalidad, sólo rota por el leve giro de la cabeza y la posición divergente de los pies.

Todo esto nos lleva a proponer una datación del Lar del MAPB en torno al s. III d.C., puesto que se aprecian en ella muchos de los elementos que definen la escultura tardorromana (frontalidad, falta de organicidad, estilización de las formas, esquematismo, trabajo del ojo o el particular uso del trépano). Se encuentra alejada aún, sin embargo, de los modelos constantinianos, en los que todas estas características son mucho más marcadas ${ }^{18}$.

\section{PROPUESTA DE CONTEXTO E INTERPRETACIÓN DE LA PIEZA}

La falta de contexto del Lar del MAPB es uno de los principales problemas para su interpretación. Las únicas referencias, dadas por Romero de Castilla, son su aparición «en las inmediaciones de Mérida» ${ }^{19}$ y la presencia de una hoz y una podadera a sus pies. Pero existe alguna certeza que la propia pieza nos da como punto de partida. La primera es su uso cultual, ya que las representaciones de Lares están siempre asocia-

\footnotetext{
${ }^{18}$ Dado que nuestra propuesta de datación tiene como única base posible el estudio estilístico e iconográfico, algunas de cuyas características abarcan un arco cronológico mayor que el de la fecha propuesta, ésta deberá ser ajustada cuando se encuentren nuevos paralelos que confrontar con la pieza, especialmente si poseen un contexto estratigráfico.

${ }^{19}$ Según una información hoy perdida, parece que la pieza pudo hallarse en las cercanías del acueducto de los Milagros. De ser así, procedería posiblemente de una domus suburbana.
} 


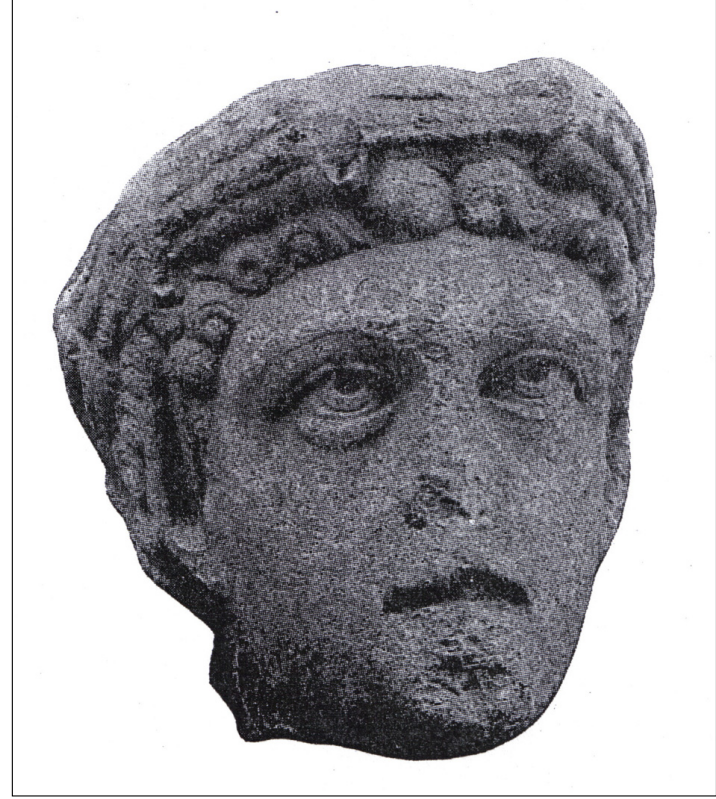

Fig. 9. Cabeza de sátiro o Fauno procedente de Aquileia (Udine, Italia) (Vergnani, 1964, lám. LXV, 127).

das a contextos de culto, público o privado. La faceta pública está documentada en Mérida en la inscripción dedicada a los Lares augusti procedente del sacrarium dedicado al culto imperial en la ima cavea del teatro (Trillmich, W., 1989-1990). Sin embargo, la pieza de la que nos ocupamos carece de la calidad (técnica y material) que caracteriza a la es- cultura oficial de la capital lusitana, lo que nos lleva a proponer un ámbito privado de procedencia. Precisamente Álvarez Martínez (1975, 869) sugiere como contexto una de las villas del entorno.

En el ámbito privado, urbano o rural, los Lares son representados en las capillas domésticas mediante pintura o esculturas, pero de los lararios con contextos cerrados conocidos a lo largo del Imperio, aquellos con escultura han documentado en su mayoría bronces de pequeño formato. En comparación las imágenes en piedra son muy escasas. El ejemplo más destacado es el sacrarium (Fig. 11) de la Via Giovanni Lanza (Roma), bajo la iglesia de San Martino ai Monti. Construido como Iseo (s. II d.C.), en el s. IV fue englobado en el patio de una suntuosa casa como capilla familiar (Ensoli, S., 2000, 280). La presidía una estatua de Isis-Fortuna de $146 \mathrm{~cm}$ de altura, colocada en la exedra de fondo y rodeada por otras esculturas en piedra de pequeño formato en nichos laterales.

El Lar del MAPB es, por tanto, otro ejemplo de estatua de culto doméstico en piedra, si bien ninguno de los conocidos representa a esta divinidad. Por su tamaño y el somero trabajo de su parte posterior, es verosímil pensar que se situase también en el interior de un sacrarium, adosado a su pared de fondo o en una hornacina. El caso de San Martino es, sin embargo, algo excepcional por el tamaño de la capilla y por la cantidad de imágenes que lo componen. La reconstrucción (Visconti, C. L., 1885, láms. III y XIII) evoca los complejos lararios que describe la Historia Augusta en el palacio de Severo Ale-
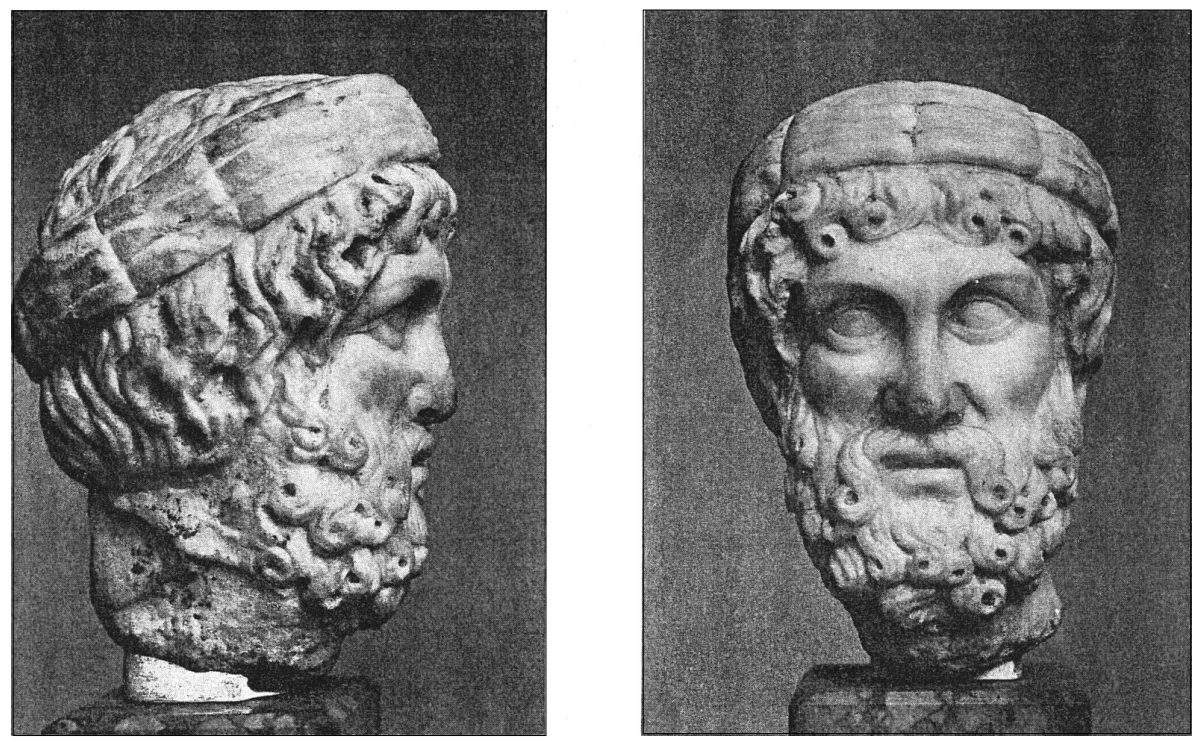

Fig. 10. Retrato de sacerdote (Poulsen, 1974, lám. CCCLX, fig. 210). 


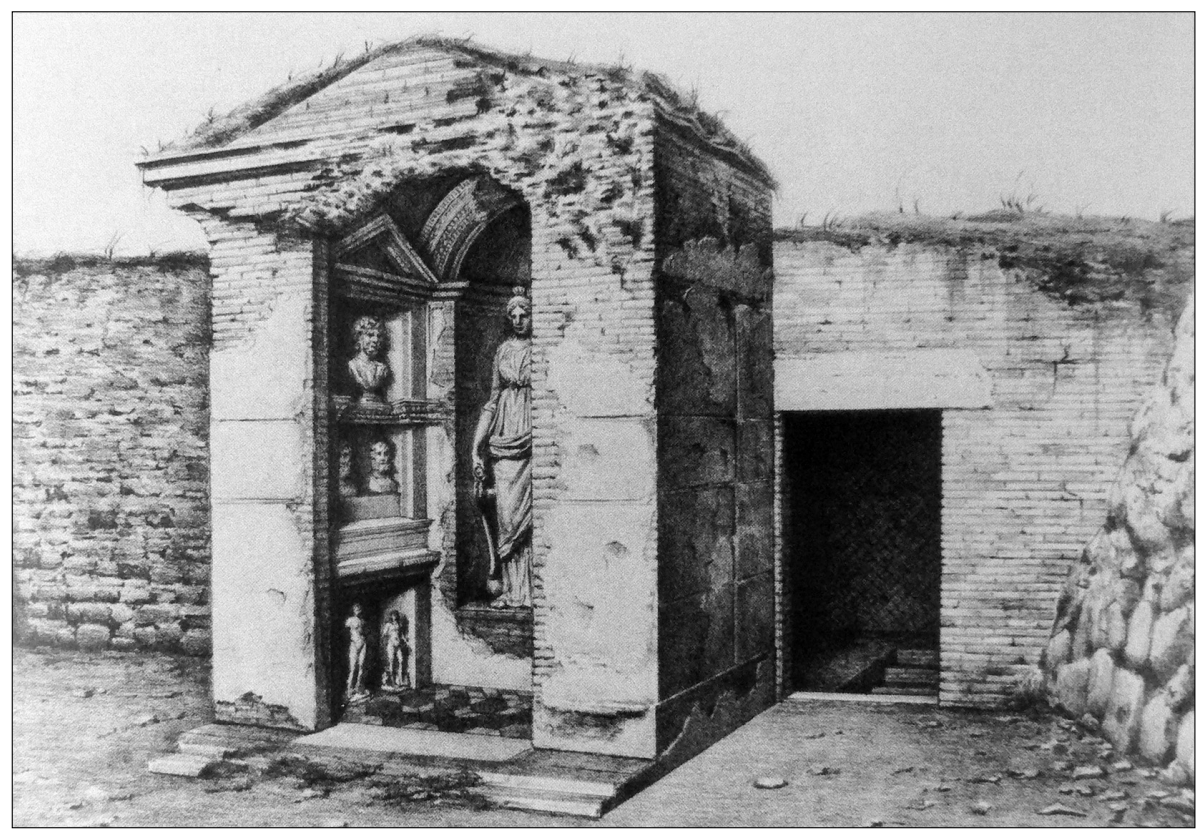

Fig. 11. Sacrarium de San Martino ai Monti (Visconti, 1885, lám. III).

jandro, poblados de imágenes de numerosos personajes divinizados (Hist. Aug., Alej. Sev. 29, 2 y 31, 4), cuya presencia en una capilla doméstica es algo anómala, pero que deben ser considerados no tanto como divinidades protectoras sino más bien como eminencias dignas de la admiración del propietario, en este caso el propio emperador. Este ejemplo nos ofrece una visión de los lararios como espacios del culto doméstico sujetos a las preferencias de sus propietarios y que se habían ido enriqueciendo con nuevos «inquilinos», fruto de las mutaciones en la espiritualidad de la sociedad romana y que se sumaban a las tradicionales divinidades protectoras, las cuales siguieron siendo, a pesar de ello, el objeto principal de veneración privada hasta los últimos coletazos del paganismo, como demuestra el Codex Theodosianus (16, 10, 12).

Además de este sacrarium conocemos otros ejemplos que podrían haber albergado estatuas de culto de grandes dimensiones, posiblemente en piedra, y pueden aproximarnos al contexto buscado. Es el caso del larario (Fig. 12, núm. 16) de la Casa de los Delfines en Thysdrus (El Djem, Túnez. Bullo, S. y Ghedini, F., 2003, II, 310, Thysdrus 13; Bassani, M., $2005,85)$, situado al fondo del patio inmediatamente posterior al ingreso, de manera que entraría en el campo visual de cualquiera que accediese a la casa. El sacrarium está formado por un espacio rectangular y un ábside de fondo precedidos por un mínimo umbral; cada una de las tres partes está diferenciada mediante una decoración musiva propia que, en el caso del ábside, se limita a un tapiz blanco destinado a no ser visto y sobre el cual debió colocarse en consecuencia un altar o una estatua de culto (Bassani, M., 2005, 85). Otro ejemplo significativo es el sacrarium (Fig. 13, núm. 19a) de la Villa Filosofiana de Piazza Armerina (Italia. Bassani, M., 2003, 164165; Carandini, A. et alii 1982; Ampolo, C. et alii 1971). Éste se encuentra en el lado E. del primer peristilo, a pesar de lo cual forma un conjunto con el vestíbulo anterior, con el que comparte una orientación propia (Carandini, A. et alii 1982, 123), vinculación más evidente por el emblema del vestíbulo, una posible representación del ritual del Año Nuevo conectado con el culto a los Lares (ibid., 66). Tiene una planta cuadrangular rematada en ábside y precedida por un estrecho umbral, todo ello pavimentado con mosaico de tema geométrico y vegetal, a excepción del ábside, de teselas únicamente blancas, donde hay colocado un pedestal de obra para una estatua. Tiene un marcado carácter oficial que le viene dado por su monumentalidad (paredes cubiertas de mármol y cuatro columnas en sus esquinas interiores), por su ubicación en la mitad oficial del peristilo y por su vinculación con el vestíbulo (ibid., passim). Su posición en el conjunto de la villa obligaba a todo aquel que se dirigiese a la basílica a pasar por delante de él (ibid., 125). 


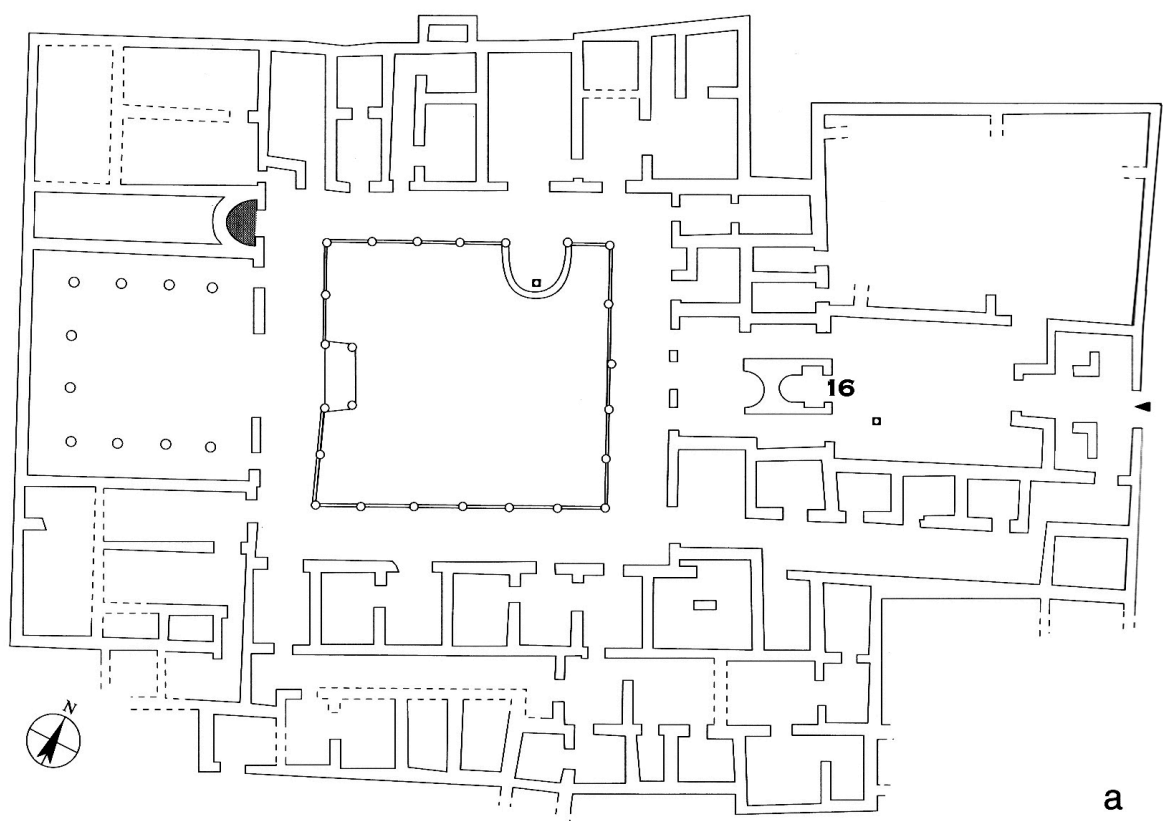

Fig. 12. Sacrarium de la Casa de los Delfines, Thysdrus (El Djem, Túnez), con indicación del vano 16 (Bassani, 2003, lám. VI.a).

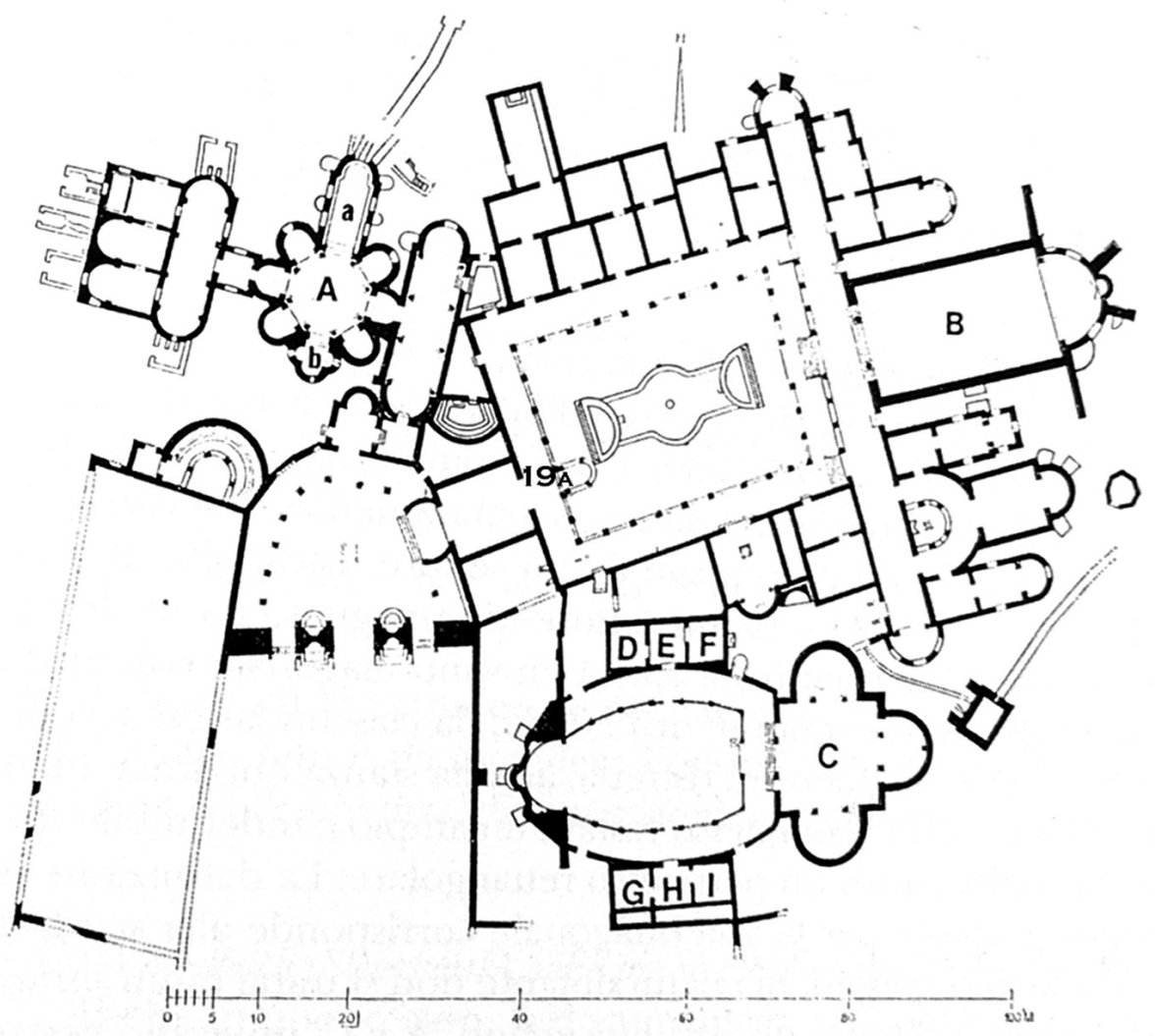

Fig. 13. Sacrarium de Villa Filosofiana, Piazza Armerina (Italia), con indicación del vano 19a (Scagliarini, 1995, fig. 6). 
La cronología de ambos sacraria es tardía, del s. III d.C. para la Casa de los Delfines (si bien el mosaico del sacrarium se ha datado en el s. IV) y de principios del s. IV para Villa Filosofiana (320-330 d.C. aprox.). Ambos, al igual que el de San Martino ai Monti, están datados en un período algo posterior al del Lar del MAPB pero responden a un fenómeno que puede aportar algunos datos para la explicación de esta pieza.

Hay una peculiaridad especialmente reseñable y es la posición de estas capillas en espacios abiertos, en la parte pública y oficial de la casa y, sobre todo, visibles desde el ingreso principal, desde el cual se accede a éstas directamente ${ }^{20}$. Esto marca una importante diferencia respecto a los lararios altoimperiales, cuyo mejor muestrario encontramos en Pompeya. En esta ciudad es frecuente la presencia de éstos en espacios de acceso público, pero muy frecuentemente algo apartados de los principales recorridos y ejes visuales de la casa, ligeramente descentrados respecto a éstos o parcialmente escondidos tras elementos arquitectónicos ${ }^{21}$. La posición preferente de los lararios tardoantiguos parece responder, por tanto, a un interés del dominus por manifestar su pietas de una forma ineludible ante la mirada del visitante, mediante un lenguaje de escenografía arquitectónica en el que la posición, la orientación y la rica decoración de la capilla doméstica ${ }^{22}$ transmiten el mensaje del cumplimiento de los ritos preceptivos a las divinidades de la casa y del mantenimiento de las antiguas tradiciones. Su explicación reside en la dimensión pública y oficial de la residencia romana tardoantigua, que ahora se pone al servicio de una poderosa aristocracia atomizada en territorios muy concretos y que busca, mediante la ostentación y el lujo exagerados en complejas y múltiples salas de representación, evidenciar su estatus y su poder, a la vez que poner de manifiesto sus vínculos con Roma (Ensoli, S. y La Rocca, E., 2001, 19), tomando como modelo los grandes palacios imperiales ${ }^{23}$. La arquitectura es usada así como vehículo propagan-

\footnotetext{
${ }^{20}$ En el caso de San Martino ai Monti no podemos verificar si fue así, pues carecemos de una planta que nos proporcione la ubicación relativa del patio en la casa.

${ }^{21}$ Algunos ejemplos son las domus I.6.4; I.7.10-12; I.11.6; II.1.8,9; V.1.26; VI.8.5.

${ }^{22}$ Los lararios de San Martino y de Villa Filosofiana presentaban sus paredes revestidas de lastras de mármol (Bassani, M., 2003b, 171).

${ }^{23}$ La utilización de modelos imperiales en la arquitectura doméstica hispanorromana aparece ya atestiguada en el s. II d.C. en el yacimiento de Itálica, donde el triclinio de la Casa de los Pájaros, con sus dos jardines adyacentes, recuerda el conjunto triclinar de la Domus Flavia en tiempos de Domiciano (García y Bellido, A., 1960, 85-86).
}

dístico y de autorrepresentación en manos de los miembros destacados de la sociedad provincial, que buscan hacer evidente y reafirmar su posición mediante la referencia a la figura central del emperador y su casa. Para ello hipertrofian espacios socialmente relevantes de la residencia, como el larario, que tradicionalmente había formado parte de los elementos legitimantes que arropaban al dominus en el atrio de su casa y que, como integrante de las antiguas tradiciones romanas, representa el respeto y fomento de éstas.

Éstas son las coordenadas en las que nos parece verosímil insertar la estatua del Lar del MAPB. Un sacrarium de similares características a los descritos, ubicado en un espacio abierto y destinado a contener una estatua de culto de dimensiones relativamente grandes. Cabe la posibilidad de que ésta no fuera la única imagen del larario ni la principal, ya que los Lares no aparecen nunca como única divinidad venerada en la capilla doméstica y, frecuentemente, son representados como acompañantes del Genio. En el caso de haberse tratado de la única imagen del larario, esta anomalía debería explicarse en el contexto de la evolución durante siglos de la concepción del culto doméstico, que hizo aún más flexibles las manifestaciones de piedad, añadido a la inevitable reinterpretación que éste sufre en su difusión por las provincias. En Hispania no se ha documentado ningún ejemplo de larario que responda a estas características y que coincida con la cronología propuesta para el Lar. Existe, sin embargo, un caso de sacrarium rematado en ábside en la Casa de los Pájaros de Italica (Santiponce, Sevilla. García y Bellido, A., 1960, 85-86 y figs. 22 y 25; Bassani, M., 2005, 77-78, 84-85, 89 y figs. 3-4), datado en el s. II d.C. y similar a los de la Casa de los Delfines y Villa Filosofiana, el cual es una muestra de la presencia de este tipo de espacios para el culto doméstico en la Península Ibérica.

En el ámbito rural, las evidencias halladas en las villas de este período no son suficientes como para poder reconocer en ellas la presencia inequívoca de lararios, que sin duda debieron existir (Bowes, K., 2006, 75). Hace algunos años se propuso la lectura como capilla familiar de dos espacios, uno octogonal y el otro circular, hallados en sendas villas sorianas, Los Quintanares (Rioseco) (Ortego, T., 1969; 1976; 1977) y Los Villares (Santervás del Burgo. Ortego, T., 1961). Su excavador se basaba en la planta de estas estancias, con la presencia de hornacinas en sus ángulos, para avanzar esta hipótesis (Ortego, T., 1961, 226; 1969, 237-238). En El Saucedo (Talavera de la Reina, Toledo) se ha sugerido también este 
uso para una estancia similar ${ }^{24}$ (Aguado, M. et alii 1999, 203). En el caso de la villa de Los Quintanares, durante la excavación del impluvium se halló además una estatua de Saturno ${ }^{25}$ con la parte trasera apenas trabajada, que se asoció a los restos de «otros lares o penates de los que contamos posibles vestigios» (Ortego, T., 1976, 362, fig. 5); el conjunto de estas esculturas podría asociarse indirectamente al espacio poliabsidial interpretado como larario y apoyar así esta hipótesis. Sin embargo, los términos «lares o penates» están usados de forma demasiado ambigua y carecemos de más datos o de imágenes que nos permitan discernir de qué divinidades se trataba exactamente $^{26}$. Para el caso de Los Villares, el emblema de Ceres en el pavimento de mosaico, el hallazgo de fragmentos de esculturas en mármol y la interpretación de ábsides como armaria lararia llevaron a su excavador a considerar la estancia como una capilla doméstica (Ortego, T., 1961, 226). Pero esta interpretación es arriesgada para ambos espacios y la presencia del mosaico o las esculturas no es, en este caso, signo inequívoco de un uso cultual ${ }^{27}$.

La hipótesis resulta sugerente, especialmente para el caso de nuestro Lar, puesto que ofrecería un contexto teórico con múltiples hornacinas que avalaría la presencia de más de una estatua de similares características a las suyas. Sin embargo, carecemos de evidencias suficientes que avalen su veracidad por el momento. Por otro lado, este tipo de salas se identifican en las villas tardoantiguas con espacios de recepción y representación (Balmelle, C., 2001, 173 y figs. 64-65), sin otorgárseles un uso específicamente cultual ${ }^{28}$.

${ }^{24}$ La planta en este caso es cuadrangular con los ángulos rematados en ábside.

${ }^{25}$ Estatua de mármol blanco y $42,5 \mathrm{~cm}$ de altura.

${ }^{26}$ En ninguna de las demás publicaciones de Ortego sobre la villa se añade información sobre estos restos de imágenes de culto.

${ }^{27}$ No conocemos casos de hornacinas utilizadas como armaria lararia. Por otro lado, la presencia de un mosaico con representación de divinidades en ámbito doméstico no implica necesariamente un uso cultual del espacio en el que se encuentra y, de hecho, los mosaicos que pavimentan los lararios considerados inequívocamente como tales en Hispania y otras zonas (Piazza Armerina, por ejemplo) son geométricos y/o vegetales. Las esculturas, por su parte, no están bien identificadas y en ningún caso hacen referencia a divinidades claramente asociadas al culto doméstico.

${ }^{28}$ Un completo estudio de este tipo de salas en la arquitectura tardoantigua, que pone de manifiesto la versatilidad de su uso, en Scagliarini, D., 1995. De ellas dice: «...i vani poligonali nelle residenze tardoantiche hanno in comune solo la capacità di evocare suggestivamente modelli dell'architettura aulica, conferendo con immediatezza all'ambiente una connotazione di prestigio» (873). El uso cultual asociado a un larario no se contempla, sin embargo, en ninguno de los casos analizados, entre los cuales se encuentra la villa de Los Quintanares (860-861).
Cabe aún explicar la presencia de la hoz y la podadera halladas a sus pies. Dada la falta de algún otro dato, no es posible ofrecer una única hipótesis sobre su presencia. Se han documentado espacios de culto doméstico con contextos cerrados en los que han aparecido objetos relacionados con la actividad agrícola junto a esculturas y objetos de culto, pero no parece verosímil que una escultura de las características de la que aquí estudiamos se hallase en un ambiente de servicio, tal como un almacén o un espacio dedicado a la producción agrícola ${ }^{29}$. La asociación del Lar con estos aperos puede ser fruto del desorden ocurrido en el momento de su abandono o bien de su ubicación junto a algún espacio de almacenaje o dedicado a usos agrícolas.

Sin embargo, existe una hipótesis más sugerente que los vincularía de forma más directa y que creemos interesante esbozar aquí. La presencia de la hoz y la podadera junto al Lar se puede relacionar con una serie de evidencias que, a lo largo de los siglos, mantuvieron la vinculación de los Lares con la agricultura y con la naturaleza, la cual habría estado en el origen de los Lares y en su naturaleza primitiva según una de las dos teorías aceptadas sobre este tema ${ }^{30}$. En primer lugar, el Lar del MAPB (del tipo II) porta la cornucopia, símbolo de abundancia, prosperidad y fertilidad, ligado a divinidades de la naturaleza como Ceres. Por otro lado, la vestimenta, una túnica corta, y el calzado, un tipo singular de bota de caza infrecuente en las representaciones de Lares, se puede equiparar a divinidades de la naturaleza como Diana o Marte (asociado a la naturaleza en su origen). La propia corona de espigas con infulae coincide con el tocado de los Hermanos Arvales, que rendían culto a la diosa Día - conectada con la agricultura- y en cuyo canto (ss. V-IV a.C.) aparece la primera referencia a los dioses Lares, relacionados con Marte como divinidad agrícola (Petruševski, M. D., 1967, 417). La vinculación de los Lares con la naturaleza no se limita a la tradición arválica, sino que se pueden trazar conexiones con múltiples divinidades asociadas a este mismo ámbito, como Silvano, Pan o Fauno (Rodríguez Oliva, P. 1994, 31). El propio Silvano tiene una dimensión doméstica recogida por la epigrafía (Bulard,

\footnotetext{
${ }^{29}$ Los contextos teóricos que hemos propuesto para la pieza son, de hecho, incompatibles con esta posibilidad.

${ }^{30}$ Frente a esta teoría que enfatiza su naturaleza como dios del lugar, está la que considera a los Lares como divinidades conectadas con los antepasados y el mundo ultraterreno. Ambas, sin embargo, tienen algunos puntos de conexión, como el carácter ctonio de la divinidad, su relación con el ciclo de la vida y la muerte o con la perduración de la estirpe.
} 


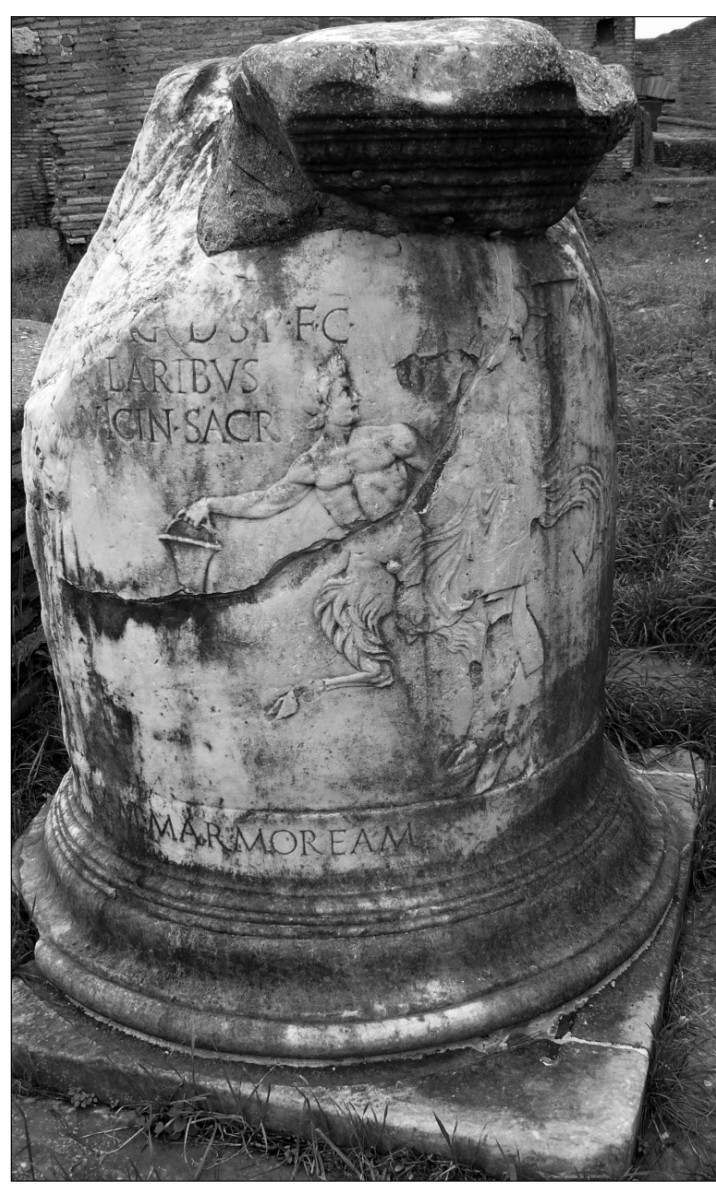

Fig. 14. Altar hallado en Ostia Antica (Ostia, Italia). Detalle con la dedicación a los Lares y la representación de un Fauno y un Lar en uno de sus lados (@M. Pérez Ruiz).

M., 1923, 463, n. 5) y por algunas pinturas de culto privado (ibid., 463; Plassart, A., 1916). Pero quizá lo más interesante de esta dimensión agrícola y natural de los Lares sea su constatación epigráfica en el epíteto agrestis, documentado en una inscripción conservada en el lapidario vaticano y que subraya además su relación con Silvano:

\section{Silvano / Lari agresti / A. Larcius Pro / culus d. d. ${ }^{31}$}

La inscripción encuentra su representación iconográfica en un ara (Fig. 14) hallada en Ostia (Calza, G., 1916). En el centro de su relieve aparece Hércules junto a un altar cuadrangular colocado delante de un árbol. A ambos lados dos Faunos que portan cada uno una sítula acompañan a dos figuras que, por la

\footnotetext{
${ }^{31}$ C.I.L. VI, 646.
}

vestimenta y por la inscripción, pueden ser identificadas como Lares:

\section{(vicom)ag(ister) (d)e s(ua) p(ecunia) f(aciundum) c(uravit) Laribus vicin(is?) sacrum}

La propia cabeza de Aquileia muestra a una divinidad tocada con una corona casi idéntica a la del Lar y peinada de igual manera y que se asocia por su tocado a las ceremonias arválicas (Vergniani, M., 1964, 203). El mismo autor, ante la ausencia de evidencias de este colegio sacerdotal en Aquileia, prefiere identificarla con Fauno.

Aunque el origen y la naturaleza de los Lares es un tema complejo, sí parece clara su vinculación al entorno natural domesticado o semidomesticado. Esta vinculación, evidente ya desde el carmen de los Arvales y en sus competencias más antiguas (Lares compitales), no parece abandonarlo a pesar de los siglos y del olvido en el que caen las atribuciones originales de estas divinidades domésticas, que van conformando una especie de masa de dioses protectores cuyos límites entre sí se difuminan. El Lar del MAPB, una pieza singular de arte provincial parece recordar de nuevo, en el s. III d.C. y en uno de los extremos del Imperio, la dimensión original de estas divinidades, agrícola y vinculada con la naturaleza, que queda respaldada por su iconografía y por el único contexto que lo acompaña, a la vez que lo explica.

\section{CONCLUSIONES}

La escultura de Lar del MAPB fue hallada al margen de cualquier actividad arqueológica científica. La consecuente falta de contexto y los limitados materiales asociados hacen difícil su análisis e interpretación. Sin embargo, sus propias peculiaridades la convierten en una pieza de gran interés para el estudio del culto doméstico, tanto en la Península Ibérica como en el conjunto del Imperio. Su realización en piedra y sus dimensiones no son equiparables por el momento a ningún otro hallazgo de dios Lar en ninguna parte del Imperio, lo cual indica una singularidad cuyo intento de interpretación puede ofrecer nuevos datos para el conocimiento de un aspecto de la religión romana en el que se adolece de información suficiente y fiable para la época en que se fecha la escultura. El análisis cruzado de estructuras sin apenas materiales junto con materiales sin estructuras en las que contextualizarlos puede aportar luz, siquiera de manera teórica, a un panorama tan poco claro como es el culto doméstico romano en época 
tardoantigua que, según las fuentes, siguió existiendo amparándose en la privacidad de la casa. Las peculiaridades de esta pieza parecen poner a la vez de manifiesto las transformaciones y las pervivencias del culto doméstico en época tardorromana. El larario propuesto como contexto teórico de la escultura deja de ser un espacio eminentemente privado para pasar a ser una de las estancias de representación y prestigio que, mediante su hipertrofia, sirven a la aristocracia para sancionar y ratificar su posición social en su propia morada, manteniendo a la vez un recuerdo de la naturaleza y atribuciones conferidas al Lar, asociadas a la agricultura y la subsistencia de la familia romana.

Pero la escasez de datos hace difícil defender con decisión cualquiera de las hipótesis expuestas sobre el contexto e interpretación del Lar del MAPB. Los ejemplos que jalonan el Imperio nos han permitido lanzar alguna pero mientras que no hallemos una pieza de similares características y contextualizada será difícil aportar certezas en la interpretación de esta escultura tan singular.

\section{BIBLIOGRAFÍA}

Aguado, M.; Castelo Ruano, R.; Torrecilla, A.; Arribas, R.: Jiménez, O.: Sierra, C. y Taléns, C., 1999: «El yacimiento arqueológico de El Saucedo (Talavera la Nueva, Toledo): balance y perspectivas», CuPAUAM 25 (2), 193-250.

Álvarez Martínez, J. M. ${ }^{a}, 1975$ : «Una estatua de Lar en el Museo de Badajoz», RABM 78 (2), 869-890.

Álvarez Martínez, J. M. ${ }^{a}$ y Nogales Basarrate, T., 1992-1993: «Algunas consideraciones sobre la decoración de villae del territorium emeritense: musivaria y escultura, Studia Historica». Historia Antigua X-XI, 273-295.

Ampolo, C.; Carandini, A.; Pucci, G. y Pensabene Pérez, P., 1971: «La villa del Casale a Piazza Armerina. Problemi, saggi stratigrafici ed altre ricerche», MEFR 83 (1), 141-281.

Balmelle, C., 2001: Les demeures aristocratiques d'Aquitaine. Société et culture de l'Antiquité tardive dans le Sud-Ouest de la Gaule. BourdeauxParis.

Bassani, M., 2003: «Gli spazi cultuali, Amplissimae atque ornatissimae domus (Aug. civ., II, 20, 26)». L'edilizia residenziale nelle città della Tunisia romana. Saggi. Antenor Quaderni 2.1. Eds. Bullo, S. y Ghedini, F. Roma, 153-187.

- 2005: «Ambienti e edifici di culto domestici nella Penisola Iberica», Pyrenae 36 (1), 71-116.
Boucher, S. y Oggiano-Bitar, H., 1993: «Les bronzes divins de La Cachette de Bavay (Nord)», Bronces y religión romana. Actas del XI Congreso Internacional de Bronces Antiguos. Madrid, mayo-junio 1990. Coords. Arce Martínez, J. y Burkhalter, F. Madrid.

- 1995: «Les Lares des Provinces romaines: essai de datation», en Mols, Acta of the 12th International Congress on Ancient Bronzes. Nijmegen, 1992. Eds. S. T. A. M., Gerhartl-Witteveen, A. M., Kars, H., Koster, A., Peters, W. J. Th. y Willems, W. J. H. Nijmegen.

Bowes, K., 2006: «Building sacred landscapes: villas and cult», Villas Tardoantiguas en el Mediterráneo Occidental. Anejos de AEspA, XXXIX. Eds. Chavarría, A., Arce, J. y Brogiolo, G. P. Madrid.

Bulard, M., 1923: «Sur une peinture d'autel découverte a Dèlos en 1912 et représentant un dieu chèvrepied», Bulletin de Correspondance Hellénique 47, pp. 455-487.

Bullo, S. y Ghedini, F. (eds.), 2003: «Amplissimae atque ornatissimae domus (Aug. civ., II, 20, 26)». L'edilizia residenziale nelle città della Tunisia romana, Saggi e Schede. Antenor Quaderni 2.1 y 2.2. Roma.

Calza, G., 1916: «II. Ostia-Scavi sul Piazzale delle Corporazioni, nell'isola tra il Decumano e la via della Casa di Diana», NSc XIII, 138-148.

Carandini, A.; Ricci, A. y De Vos, M., 1982: Filosofiana: The Villa of Piazza Armerina. The image of a Roman aristocrat at the time of Constantine. Palermo.

Castagnoli, F., 1966 en EAA vol. VII, s.v. «Vertumno». Roma, p. 1145.

Creus Luque, M. ${ }^{\text {a }}$ L., 2002: «Diferentes materiales escultóricos romanos en el territorio de Augusta Emerita», Materiales y técnicas escultóricas en Augusta Emerita y otras ciudades de Hispania. Cuadernos emeritenses, 20. Ed. Nogales Basarrate, T. Mérida.

Ensoli Vitozzi, S., 2000: «I santuari di Iside e Serapide a Roma e la residenza pagana in etá tardoantica, Aurea Roma». Dalla città pagana alla città cristiana. Eds. Ensoli Vitozzi, S. y La Rocca, E. Roma.

Ensoli Vitozzi, S. y La Rocca, E., 2001: «Aurea Roma». Dalla città pagana alla città cristiana. Guida alla mostra. Roma.

Esperandieu, E., 1908: Recueil General des BasReliefs de la Gaule Romaine vol. II. Aquitanie. Paris.

García y Bellido, A., 1949: Esculturas romanas de España y Portugal. Madrid. 
- 1960: Colonia Aelia Augusta Italica. Madrid.

JoRDAn, H., 1882: Larum imagines ineditae, Annali dell'Istituto di Corrispondenza Archeologica, 54, 70-73, láms. M-N.

Kozloff, A. P. y Mitten, D. G. (org.), 1988: The Gods Delight. The Human Figure in Classical Bronze. Cleveland.

Marco Mellado, H., 1999: «Dios Lar de Mérida», Hispania. El legado de Roma. Eds. Almagro-Gorbea, M. y Álvarez Martínez, J. Ma . Zaragoza, 630, $\mathrm{n}^{\mathrm{o}} 236$.

Mélida Alinari, J. R., 1925: Catálogo monumental de España. Provincia de la provincia de Badajoz (1907-1910). Madrid.

Nogales Basarrate, T., 1997: «Estatua de Ascanio», Hispania Romana. Desde tierra de conquista a provincia del Imperio. Eds. Arce Martínez, J., Ensoli Vittozzi, S. y La Rocca, E. Madrid, 390, $\mathrm{n}^{\mathrm{o}} 177$.

- 1997: «Estatuilla de Lar», Hispania Romana. Desde tierra de conquista a provincia del Imperio. Eds. Arce Martínez, J., Ensoli Vittozzi, S. y La Rocca, E. Madrid, 407, no 211.

Ortego y FríAs, T., 1961: «La villa romana de Santervás del Burgo (Soria)», VI Congreso Nacional de Arqueología. Oviedo, 1959. Zaragoza.

- 1969 (1966-1968): «Memoria de las excavaciones en la villa romana de Los Quintanares, en el término de Rioseco de Soria», NAH X-XI y XII, 235242.

- 1976: «Excavaciones arqueológicas realizadas en la villa romana de "Los Quintanares", en el término de Rioseco de Soria», NAH 4, 359-373.

- 1977: «La villa romana de "Los Quintanares" en el término de Rioseco (Soria)», Segovia. Symposium de Arqueología romana. Barcelona, 285-292.

Penny Small, J., 1997 en LIMC, vol. VIII.1, s.v. «Vertumnus». Düsseldorf, 235.

Petruševski, M. D., 1967: «L'evolution du Mars italique d'une divinité de la nature a un dieu de la guerre», Acta Antiqua Academiae Scientiarum Hungaricae 15, 417-422.

Plassart, A., 1916: «Fouilles de Délos exécutées aux frais de M. le Duc de Loubat (1912-1913)», BCH XL, 145-256.

Portela Filgueiras, M. ${ }^{a}$ I., 1984: «Los dioses Lares en la Hispania romana», Lucentum 3, 153-180.

Poulsen, V., 1974: Les portraits romains. Vol. II: De Vespasien à la Basse-Antiquité. Copenhague.

Putnam, M. C. J., 1967: «The shrine of Vortumnus», AJA 71, 177-179.

Rodríguez Oliva, P., 1994: «Materiales arqueológicos y epigráficos para el estudio de los cultos do- mésticos en la España romana», Actas del VII Congreso Español de Estudios Clásicos, vol. III. Madrid, 23-28 septiembre 1991. Madrid.

Romero de CAstilla, T., 1896: Inventario de los objetos recogidos en el Museo de la Comisión Provincial de Monumentos de Badajoz vol. 4.

SCAGliarini Corlàtta, D., 1995: «Gli ambiente poligonali nell'architettura residenziale tardoantica», XLII Corso di Cultura sull'Arte Ravennate e Bizantina. Rávena, 14-19 mayo 1995. Rávena.

SCRINARI, V. S. M., 1972: Museo Archeologico di Aquileia. Catalogo delle sculture romane. Roma.

Segarra Crespo, D., 2003: «Las coordenadas espaciotemporales del dios Vertumnus», Transcurrir $y$ recorrer. La categoría espacio-temporal en las religiones del mundo clásico. Ed. Segarra Crespo, D. Roma-Madrid, 129-163.

Sogliano, A., 1899: «Pompei. Relazione degli scavi fatti durante il mese di maggio $1899 », N S c$, 203208.

STRONG, E., 1926: La scultura romana da Augusto a Costantino vol. I. Firenze.

Tran Tam Tinh, V., 1992 en LIMC, vol. VI.1, s.v. «Lares». Zürich y München, 205-212.

Trillmich, W., 1989-1990: «Un sacrarium de culto imperial en el teatro de Mérida», Anas 2-3, 87 102.

- 1997: «Estatua togada», Hispania Romana. Desde tierra de conquista a provincia del Imperio. Eds. Arce Martínez, J., Ensoli Vittozzi, S. y La Rocca, E. Madrid, 396, no 190.

VERGNANI, M. (coord.), 1964: Arte e civiltà romana nell'Italia settentrionale dalla Repubblica alla Tetrarchia. Catalogo, vols. I y II. Bologna.

Visconti, C. L., 1884-1885: I monumenti del Museo Torlonia riprodotti con la fototipia. Roma.

- 1885: «Del Larario e del Mitreo scoperti nell'Esquilino presso la chiesa di S. Martino ai Monti», Bullettino della Commisione archeologica comunale di Roma, 13, 27-38.

Walters, H. B., 1899: Catalogue of bronzes, Greek, Roman, and Etruscan, in the Deparment of Greek and Roman Antiquities. London.

Referencias a autores clásicos:

- Codex Theod. 16, 10, 12.

- Historia Augusta. Alejandro Severo 29, 2 y 31, 4.

- Petronius, Satyricon, 60.

- Tibullus I, 10, 15-20. 